\title{
A Comparative Study on Epidemiology, Spectrum and Outcome Analysis of Physical Trauma cases Presenting to Emergency Department of Dhulikhel Hospital, Kathmandu University Hospital and its Outreach Centers in Rural Area
} Shrestha $R,{ }^{1}$ Shrestha SK, ${ }^{2}$ Kayastha SR, ${ }^{1}$ Parajuli N, ${ }^{1}$ Dhoju $D,{ }^{1}$ Shrestha $D^{1}$

\begin{abstract}
${ }^{1}$ Department of Orthopedics and Traumatology
${ }^{2}$ Department of Emergency

Dhulikhel Hospital- Kathmandu University Hospital Kathmandu University School of medical Science
\end{abstract}

Dhulikhel Hospital, Kavre, Nepal

\section{Corresponding Author}

Rohit Shrestha

Department of Orthopedics and Traumatology

Dhulikhel Hospital- Kathmandu University Hospital Kathmandu University School of medical Science

Dhulikhel, Kavre, Nepal

E-Mail: rohitshrestha79@gmail.com

Citation

Shrestha R, Shrestha SK, Kayastha SR, Parajuli N, Dhoju D, Shrestha D. A Comparative Study on Epidemiology, Spectrum and Outcome Analysis of Physical Trauma cases Presenting to Emergency Department of Dhulikhel Hospital, Kathmandu University Hospital and its Outreach Centers in Rural Area. Kathmandu Univ Med J 2013;43(3):241246.

\begin{abstract}
Background

Physical trauma is one of the major cause of mortality and morbidity among young and active age group and its increasing trend is of main concern. There are only few studies concerning the spectrum of physical trauma in Nepal.
\end{abstract}

\section{Objective}

This study aims to evaluate the epidemiological spectrum, the extent, severity of the physical trauma and the outcome evaluation of patients with physical trauma over a period of one year in the emergency department of the Kathmandu University Hospital and compare the same parameters with those patients presenting to the various outreach centers of the hospital in the community.

\section{Methods}

Patient treatment files from the emergency department and the reports from various outreach centers were retrieved for a period of one year (May 2011 to April 2012). Epidemiological information, mode, type and anatomic location of injuries were recorded. Outcome evaluation was assessed by number of patients discharged from emergency department of the hospital or the outreach centers after the treatment, patients admitted for inpatient management and referred to other centers for further specialty management.

\section{Result}

In a period of one year, total $2205(20 \%)$ of physical trauma cases presented to the emergency department and 1994 (6.12\%) in the outreach centres. Most commonly involved age group in physical trauma both in Hospital set up and in Community set up were the young adults ( 15 to 49 years). Fall from height was the commonest mode of injury followed by road traffic accidents among the patients coming to the hospital while significant number of trauma patients coming to outreach centers were due to fall from height. In the hospital set up, 1525 (69.2\%) of the cases were discharged while 537 (24.4\%) needed inpatient management and 85 (3.8\%) needed referral to other centers for the specialty management. In case of outreaches, half of the patients were discharged after the primary treatment and almost another half were referred to the hospital, mainly for need of further investigations.

\section{Conclusion}

Fall related injuries and road traffic accidents are the most common mode of trauma in the hospital set up and fall related injuries are the single most important mode of trauma seen in the outreaches. Mostly young adults in their active period of life are involved in physical trauma so appropriate preventive measures through public health approach should be included in comprehensive trauma management for reducing mortality and morbidity rates related to physical trauma.

\section{KEY WORDS}

Emergency department, outreach centers, physical trauma, trauma center 


\section{INTRODUCTION}

Physical trauma is one of the major public health problem worldwide. In its various forms, like fall related injuries, road traffic accidents, physical assaults and other forms of violence cause more than five million death per year which makes around nine percent of global mortality. ${ }^{1}$ More than $90 \%$ of world's injury related death occurs in low and middle income countries, for which South-East Asia and Western Pacific regions account for the highest (26\%) for injury related death. ${ }^{2}$ Disability due to violence and injuries is increasing in Nepal, and accounts for about eight percent of death. This is mainly attributed to population growth, modernization and changing patterns of lifestyle of the people. Injuries, violence and disabilities have become a major public health problem in Nepal as well. ${ }^{3}$

The information received from injury surveillance helps in understanding the extent of problem, the pattern of injuries, high-risk population, seasonal trend and compares the problem among and within the geographical area which helps in creating awareness and in further planning. ${ }^{4}$ Limited studies so far are available in literatures regarding the study on epidemiology, patterns and outcome of physical trauma in a hospital set up and even fewer studies are there from community set up. Since Dhulikhel Hospital is a tertiary care center as well as University Hospital, it runs various outreach clinics in various rural set up of different districts. As a community conceived hospital, it is relevant for us to carry out a hospital based study and compare the same parameters in the community setting. Such type of study is not only important for the clinicians to plan treatment at individual level, but they are also important for educational and policy making purpose. Hence, this retrospective study was undertaken to assess the epidemiology, pattern and outcome of physical trauma coming to emergency department of Dhulikhel Hospital, Kathmandu University Hospital and compare the same parameters with trauma cases seen in community setup.

\section{METHOD}

All the patients presenting to emergency department of Dhulikhel Hospital, Kathmandu University Hospital, from May 2011 to April 2012 with all kinds of physical trauma were included in the study. Similarly, the medical reports submitted by various outreach centers to the Department of Community Program were also retrieved for the same duration. Epidemiological information, mode, type and anatomic location of injuries were recorded. Outcome evaluation was assessed by number of patients discharged from emergency department of the hospital or the outreach centers after the treatment, patients admitted for inpatient management and referred to other centers for further specialty management.

Data was entered in Microsoft Excel and then analyzed with SPSS 16 and presented in the form of mean (percentage), appropriate figures and chart where appropriate.

\section{RESULT}

Dhulikhel Hospital not only caters trauma patients coming to emergency department as a tertiary care center, the hospital also provides health care services to the community via its 12 outreach centers in the different districts (Table 1). Over a period of one year, total 2205 (19.9\%) of patients with males almost twice as common as females presented

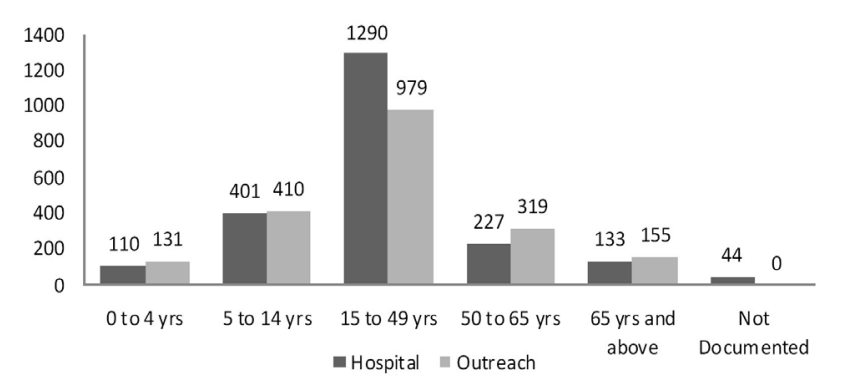

Figure 1. Age wise Distribution of patients in Hospital and in Outreaches.

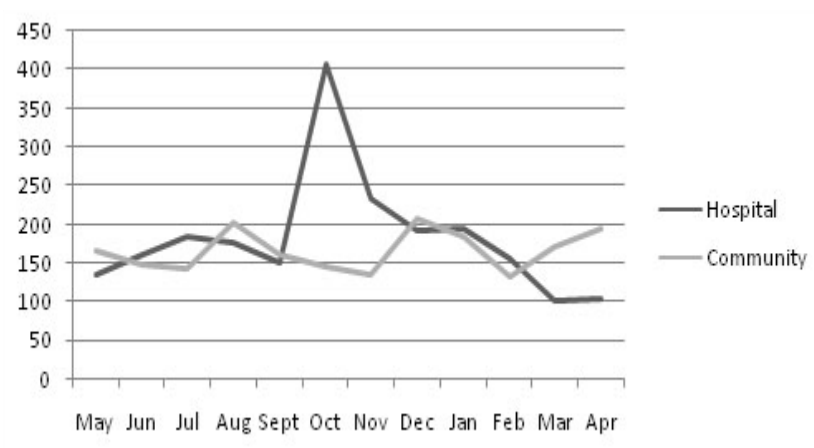

Figure 2. Month wise Distribution of Patients in Hospital and in Outreaches.

to emergency department with physical trauma while this figure was quite low 1994 (6.12\%) in over all outreaches (Table 2). Similarly, there was gradual increment in number of trauma victims with progressing age and highest number was seen in age group 15 to 49 years in both hospital setup and community setup (Fig 1). Over the year, there was a regular flow of trauma patients; on average (163.4 \pm 39.8 ) patients every month (range 105 to 235) in the emergency department and on average (166.2 \pm 26.3) in the community, however, in the month of October, the month of Dashain and Tihar festival, there were 408 trauma patients, 2.5 times more than the average in the emergency department however such a trend was not seen in the community (Fig 2). Bhramins, Chhetris, Tamangs and Newars were among the most commonly involved ethnic community representing the population distribution of the catchment area of the Hospital (Table $3)$. Among those injured persons presenting to emergency, $61.5 \%$ had some form of external injuries (Fig 3). Fall from height was the most common cause $(48.6 \%$ of total trauma cases) with $62.3 \%$ of patients requiring inpatient management, followed by road traffic accidents (30.8\%) 
Table 1. Catchment Area, Population and Total and Trauma Patients in the Outreach Centers.

\begin{tabular}{|c|c|c|c|c|c|c|c|c|c|}
\hline SN & Outreach & District & $\begin{array}{c}\text { Catchment Area - Village Development } \\
\text { Comittee }\end{array}$ & $\begin{array}{l}\text { House } \\
\text { Hold }\end{array}$ & M & $\mathbf{F}$ & $\begin{array}{l}\text { Total } \\
\text { Popula- } \\
\text { tion }\end{array}$ & $\begin{array}{c}\text { Total } \\
\text { Patient }\end{array}$ & $\begin{array}{l}\text { Total } \\
\text { Trauma } \\
\text { Patient }\end{array}$ \\
\hline 1 & $\begin{array}{l}\text { Bahunepati } \\
\text { Health } \\
\text { Center }\end{array}$ & $\begin{array}{l}\text { Sindhupal- } \\
\text { chowk }\end{array}$ & $\begin{array}{l}\text { Melamchi, Bansbari, Fatakshila, Sikarpur, } \\
\text { Sindhukot, Naghlebhare, Bhotechaur, } \\
\text { Ichock, Dubachaur, Badegaun, Iyamire }\end{array}$ & 10378 & 22605 & 24182 & 46787 & 4979 & $186(3.74 \%)$ \\
\hline 2 & $\begin{array}{l}\text { Baluwa } \\
\text { Health } \\
\text { Center }\end{array}$ & Kavre & $\begin{array}{c}\text { Dev Bhumi Baluwa, Patlekhet, Panchkhal, } \\
\text { Hokse Bazaar, Sattighar, Kharelthok }\end{array}$ & 7405 & 15712 & 17433 & 33745 & 1231 & $110(8.94 \%)$ \\
\hline 3 & $\begin{array}{l}\text { Bolde } \\
\text { Phediche } \\
\text { Health } \\
\text { Center }\end{array}$ & Kavre & $\begin{array}{l}\text { Bolde, Saramthali, Thuloparsel, Pokhari } \\
\text { Narayanthan, Chapakhori, Mechhe }\end{array}$ & 3781 & 8052 & 9350 & 17396 & 1781 & $70(3.93 \%)$ \\
\hline 4 & $\begin{array}{l}\text { Chhatre } \\
\text { Deu- } \\
\text { rali Health } \\
\text { Center }\end{array}$ & Dhading & $\begin{array}{l}\text { Chatredeurali, Jiwanpur, Jitpurphedi, } \\
\text { Dharmasthali, Ramkot, Kewalpur }\end{array}$ & 9150 & 20554 & 21356 & 41910 & 1777 & $68(3.83 \%)$ \\
\hline 5 & $\begin{array}{l}\text { Dapcha } \\
\text { Health } \\
\text { Center }\end{array}$ & Kavre & $\begin{array}{c}\text { Khanal Thok, Daraunepokhari, Pura- } \\
\text { nogaun Dapcha, Katunje Besi }\end{array}$ & 2657 & 5480 & 6298 & 11778 & 1285 & 75 (5.84\%) \\
\hline 6 & $\begin{array}{l}\text { Dhungkhar- } \\
\text { ka Health } \\
\text { Center }\end{array}$ & Kavre & $\begin{array}{c}\text { Dhungkharka, Chysingkharka, Chyrang- } \\
\text { Beshi, Mahankalchaur, Milche }\end{array}$ & 3184 & 7260 & 8037 & 15497 & 1805 & $57(3.16 \%)$ \\
\hline 7 & $\begin{array}{l}\text { Godam- } \\
\text { chaur } \\
\text { Health } \\
\text { Center }\end{array}$ & Lalitpur & Godamchaur, Thaiba, Badikhel & 3867 & 1783 & 1787 & 3576 & 3050 & $\begin{array}{c}577 \\
(18.92 \%)\end{array}$ \\
\hline 8 & $\begin{array}{l}\text { Hindi } \\
\text { Health } \\
\text { Center }\end{array}$ & $\begin{array}{l}\text { Sindhupal- } \\
\text { chowk }\end{array}$ & $\begin{array}{l}\text { Tatopani, Marming, Phulpingkatti, Listikot, } \\
\text { Bigu, Alampu, Dhumthang }\end{array}$ & 5,980 & 12092 & 12279 & 24371 & 3042 & $112(3.68 \%)$ \\
\hline 9 & $\begin{array}{l}\text { Kattike } \\
\text { Deu- } \\
\text { rali Health } \\
\text { Center }\end{array}$ & Kavre & $\begin{array}{c}\text { Kattike Deurali, Gothpani, Birtadeurali, } \\
\text { Mandankudari, Pokhari Chauri, Lakhan- } \\
\text { pur, Gunsi bhadaure }\end{array}$ & 5746 & 10699 & 12910 & 23609 & 1740 & $108(6.21 \%)$ \\
\hline 10 & $\begin{array}{l}\text { Kirnetar } \\
\text { Health } \\
\text { Center }\end{array}$ & Dolkha & $\begin{array}{l}\text { Sahare, Phulasi, Gelu, Farpu, Betali, } \\
\text { Chyama, Melung, Dandakharka }\end{array}$ & 8685 & 17984 & 21493 & 39477 & 3938 & $143(3.63 \%)$ \\
\hline 11 & $\begin{array}{l}\text { Manekhar- } \\
\text { ka Health } \\
\text { Center }\end{array}$ & $\begin{array}{l}\text { Sindhupal- } \\
\text { chowk }\end{array}$ & $\begin{array}{l}\text { Baruwa, Gunsakot, Bhotang, Thangpalkot, } \\
\text { Thampalchapp, Langarche, Banskharka }\end{array}$ & 4265 & 8822 & 8477 & 17309 & 6108 & 385 (6.3\%) \\
\hline \multirow[t]{2}{*}{12} & $\begin{array}{l}\text { Salambu } \\
\text { Health } \\
\text { Center }\end{array}$ & Kavre & $\begin{array}{c}\text { Majhifeda, Nagre Gagarche, Sanonanthali, } \\
\text { Dhuseni, Pokhari Chauri }\end{array}$ & 2408 & 4872 & 4872 & 10845 & 1815 & $103(5.67)$ \\
\hline & Total & & & & 135915 & 149575 & 286300 & 32551 & $\begin{array}{c}1994 \\
(6.13 \%)\end{array}$ \\
\hline
\end{tabular}

Table 2. Magnitude of Trauma cases in Hospital and in Community.

\begin{tabular}{|lllll|}
\hline & Hospital & \multicolumn{3}{c}{ Community } \\
\hline Male & & 1460 & & 1113 \\
Female & & 745 & & 881 \\
\hline Total(\%) & 11055 & $2205(19.94 \%)$ & 32551 & 1994 \\
& & & & $(6.12 \%)$ \\
\hline M:F Ratio & $1.96: 1$ & & $1.26: 1$ & \\
\hline
\end{tabular}

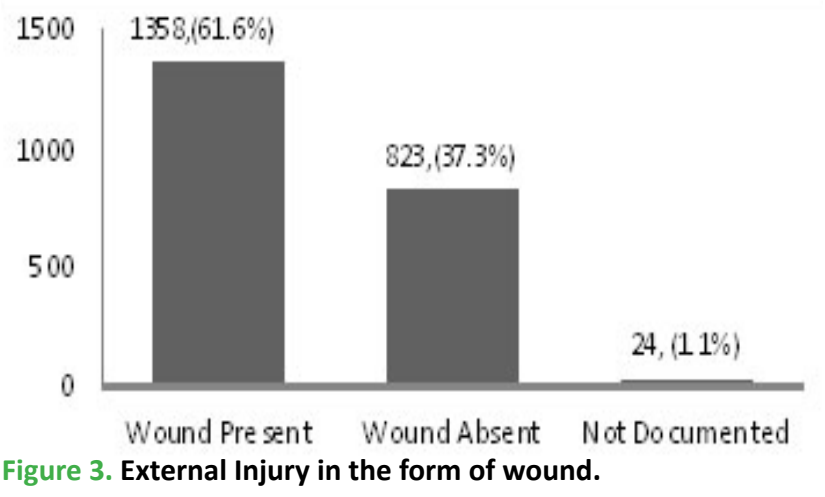


Table 3. Distribution according to Ethnicity.

\begin{tabular}{|lc|}
\hline Ethinicity & Number \\
\hline Bhramins and Chhetri & 778 \\
\hline Tamang & 494 \\
\hline Newar & 370 \\
\hline Dalit & 151 \\
\hline Rai Limbu Gurung Magar & 66 \\
\hline Madheshi & 39 \\
\hline Sherpa & 33 \\
\hline Tharu & 13 \\
\hline Other & 249 \\
\hline Not Documented & 12 \\
\hline
\end{tabular}

Table 4. Etiology of Trauma.

\begin{tabular}{|llll|}
\hline Etiology & $\begin{array}{l}\text { Hospital } \\
\text { Out of those } \\
\text { came to ER }\end{array}$ & $\begin{array}{l}\text { Community } \\
\text { Out of Ad- } \\
\text { mitted }\end{array}$ & \\
\hline Fall & $1072(48.6 \%)$ & $335(62.3 \%)$ & $111(5.6 \%)$ \\
\hline RTA & $681(30.8 \%)$ & $104(19.3 \%)$ & $1883(94.4 \%)$ \\
\hline $\begin{array}{l}\text { Physical Assault } \\
\text { Other (Animal }\end{array}$ & $184(8.3 \%)$ & $19(3.5 \%)$ & Not Available \\
$\begin{array}{l}\text { Related, Burn, } \\
\text { Natural Disaster, } \\
\text { Firearm, Occupa- } \\
\text { tion related) }\end{array}$ & $268(12.1 \%)$ & $77(14.3 \%)$ & Not Available \\
\hline Not Documented & $16(0.7 \%)$ & $2(0.3 \%)$ & 0 \\
\hline Total & 2205 & 537 & 1994 \\
\hline
\end{tabular}

among the total patients and $19.3 \%$ among the admitted patients respectively in the hospital set up; however in the community majority 1883 (94.4\%) of trauma cases were related to fall (Table 4). Injuries to extremities were more common (59.8\%) than injuries to any other anatomical locations (Fig 4) and minor injuries accounted

Table 5. Severity of the Injury in Patients coming to the Hospital.

\begin{tabular}{|c|c|c|}
\hline Severity & Definition & $\begin{array}{l}\text { Number (Per- } \\
\text { centage) }\end{array}$ \\
\hline MINOR & $\begin{array}{l}\text { Soft tissues injuries (Abrasions, } \\
\text { Bruises, Sprain etc) Phalanx and toe } \\
\text { fractures }\end{array}$ & 1391 (63.1\%) \\
\hline MODERATE & $\begin{array}{l}\text { Head, Chest \& Abdomen injuries } \\
\text { that can be managed conservatively } \\
\text { with observation and NO surgical } \\
\text { intervention needed } \\
\text { Un-displaced fractures that can be } \\
\text { managed with simple measures like } \\
\text { cast and slab } \\
\text { Isolated Displaced fracture }\end{array}$ & $610(27.6 \%)$ \\
\hline \multirow[t]{2}{*}{ SEVERE } & $\begin{array}{l}\text { Head, Chest \& Abdomen injuries } \\
\text { that need detail investigations like } \\
\text { CT Scan and probable surgical inter- } \\
\text { vention needed. } \\
\text { Multiple Injuries and poly trauma } \\
\text { Multiple fractures, Open fractures or } \\
\text { fractures associated with hemody- } \\
\text { namic instability or Unstable Spine } \\
\text { Fractures and Hip fractures. }\end{array}$ & $178(8.1 \%)$ \\
\hline & No Documentation & $26(1.2 \%)$ \\
\hline
\end{tabular}

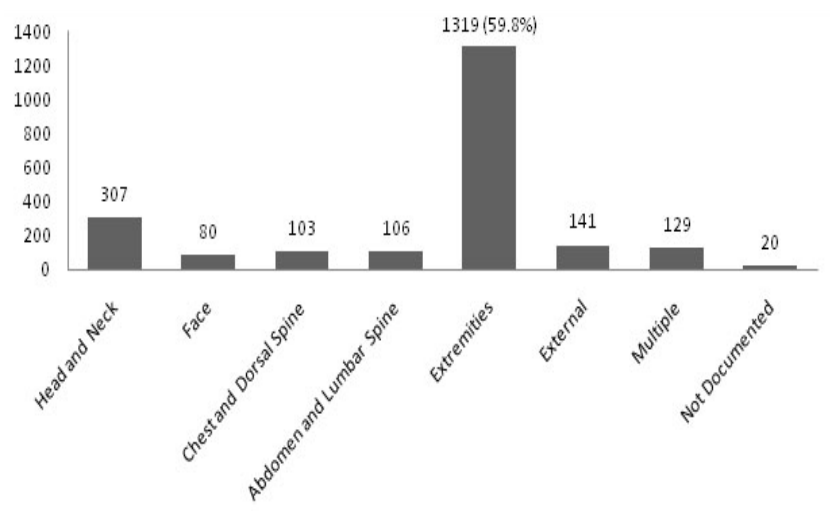

Figure 4. Anatomical Distribution of the Injury in Patients coming to the Hospital.

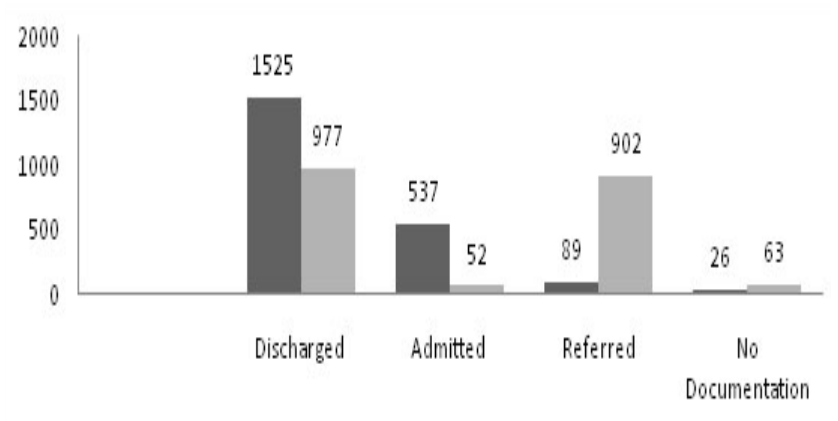

-Hospital II Community

Figure 5. Outcome status of the Trauma cases in Hospital and in Community.

the maximum number (63.1\%) while severe injuries were less (8.1\%) (Table 5). Majority of the patients 1525 (69.2\%) were discharged from the emergency department after general management while $53724.4 \%$ of trauma patients needed admission. About four percent of patients were referred to other centers for further management, majority of them (79.8\%) required computed tomography (CT) Scan. In case of outreaches, almost half of the patients 977 (49\%) were discharged and almost another half 902 (45.2\%) were referred for further evaluation and management (Fig 5).

\section{DISCUSSION}

Dhulikhel Hospital is a community conceived tertiary care university hospital and provides health care services not only to patients coming to hospital but also in community through its various outreach health centers. This study revealed that physical trauma cases accounts for about one in fifth case presenting to emergency department in Dhulikhel Hospital while it's just one in the sixteenth case in the community. The more frequent trauma cases in hospital as compared to the outreach center is obvious as hospital is the tertiary care center. The trauma prevalence in male gender was almost three times more than in female gender as females have other health related issues like woman's health apart from the other problems common to the males. Among the patients presenting with physical trauma, males were twice more commonly affected than 
females in the hospital set up. Similar findings have been reported by various other studies, where males were involved more than females. In a meta analysis of studies on injuries in south Asia, Hyder et al mentioned that majority (67 to $80 \%$ ) of injuries occurred in males. ${ }^{5}$ Similarly, an Indian epidemiological study done in Ghaziabad city also showed more male involvement, in $74.4 \%$ of cases and in another meta analysis done on injuries and violence related articles, Joshi and Shrestha, also reported that males were twice as more commonly affected than females. ${ }^{6,7}$ The reason for male preponderance may be due to their more active involvement in outdoor activities and less active involvement in outdoor activities in females in Nepalese context. The fact that male is to female ratio not too high in community may be due to the fact that females are the ones staying in villages while most of the males have travelled to cities for work.

This study also found that young people were mostly involved in physical trauma. ${ }^{8,9}$ There was a steady increase in trauma patients till the age group 15 to 49 years which constituted the maximum percentage and then, a gradual decrease in the trend with the increasing age. This can be explained due to the fact that younger people are more active and reckless, however, with increasing age people tend to be more careful and take more safety measures..$^{3-5,7}$

In this study, month of October observed the highest number of the trauma cases coming to the hospital which almost doubles the volume of cases presenting on average in other months. This was probably because in this month was the most important Hindu Festival Dashain and Tihar when people would be more involved in drinking alcohol and driving leading to more trauma cases. The location of the hospital at the junction of Araniko Highway and BP Highway makes it more likely to receive trauma patients whenever there are road traffic accidents in these highways. During the festival season, large numbers of people go to their home village from the cities usually in overcrowded buses making it more vulnerable to have accidents and more of the injury cases. Similarly, in this part of the country, which is more of the rural area, specially children and youngsters enjoy the festival with playing Ping (Swing) which is more specific of this festival and hence, fall injuries related to it is also higher in number in this month. In one of the study done in Nepal, road accidents were more common in June, July and January. ${ }^{8}$ Likewise, in another study, it is to be more common in April - May. ${ }^{10}$ Both of these studies primarily focused on road traffic accidents unlike this study which is mainly concerned with overall view on physical trauma. 8,10

Various modes of trauma have been discussed in literatures, however, fall related injuries and road traffic accidents are the commonest ones. Paudel - Tandukar et al found fall related injuries (65\%) as the most common cause and Ghimire et al also reported fall injuries as the most common mode of injury (34.8\%). ${ }^{9,11}$ However, there are some differences in designs in these two studies, the former one was a school based study which interviewed the students about their experiences in severe injuries in the last 12 months while the latter one was a community based study which interviewed the people about their experiences in injuries in the last 12 months. Whereas in a hospital based observational study which recorded all the injury cases coming to the emergency department, Joshi et al found that road traffic accidents as the most commonest mode of injury (42\%). ${ }^{7}$ The present study is similar to some extent in study design with that of Joshi and Shrestha, which was based on the patients presenting to emergency department, agrees with the findings of previous two studies stating that fall from the height is the most common cause of trauma both in hospital and in the community. Most of our villages are still deprived of motorable roads and our villages are on mountainous landscape, extremely high percentage of fall related injuries there is not surprising. Studies on other injury patterns like spine injuries from Indian subcontinent also showed the findings similar to this study, i.e due to fall from the height. ${ }^{12-14}$

Majority of the patients (61.6\%) had some forms of external wound (cut injury, lacerations or open fractures) and injury to extremities (59.8\%) were the commonest ones followed by injuries to head and neck (13.9\%) in this study. These findings were similar with other studies where Joshi and Shrestha reported $40.2 \%$ of cuts and open wounds and $21.3 \%$ of fractures. Similarly, Singh et al reported $47.2 \%$ of lacerations and $21.6 \%$ of fractutes. Meskin et al also reported $32.2 \%$ of open wounds and $25 \%$ with fractures and dislocations. However, in the study by Sharma et al, abrasions and contusions were highest (77\%) and PaudelTandukar et al reported that fractures and dislocation were the lowest $(2.2 \%)$. The difference between those two studies with our study is that those studies reviewed the postmortem reports on different causes of traumatic death and different forms of injuries and their mechanism, unlike our study which is a hospital and community based study evaluating trauma patients presenting to emergency department and outreach health centers. $6,7,11,15,16$

Injury severity score or revised trauma score would have been a standard tool for measuring trauma however, most of the literatures have adopted self defined simple criteria to measure the severity of trauma. Joshi and Shrestha had three grades of severity as minor, moderate and severe and accordingly they had 53(10.5\%), 264(52.5\%) and $176(34.9 \%)$ of cases in each category respectively. ${ }^{7}$ With almost similar criteria as that of Joshi and Shrestha, this study had different findings with $1391(63.1 \%)$ as minor, $610(27.6 \%)$ as moderate and $178(8.1 \%$ ) as major (Table 8 ) in hospital senario. These differences emerged probably because of the differences in the set up of these studies and the duration. The study done by Joshi and Shrestha was a cross-sectional study over one month period at six heath centers in two of the major cities of the country; Kathmandu and Bhaktapur however, this study was a one 
year retrospective review of emergency department of the hospital and its neighboring out reach heath centers. In another epidemiological study of injuries among the urban population, Ghimire et.al, defined severity of injury as minor if resulting in less than 30 days loss of activity and major if resulting in 30 or more days of loss of activity and with this definition they had prevalence of $3.5 \%$ and $0.7 \%$ respectively for minor and major injuries. ${ }^{9}$ However, our study was a hospital and community based study evaluating the occurrence of trauma in a general population over a period of one year. Interestingly, the findings were in agreement with this study where the prevalence of minor injuries was more compared to that of major injuries.

Majority, almost two third, of the patients presenting to the hospital were discharged after appropriate management in the emergency department and about half of the patients in the outreaches could be discharged with primary management only. In hospital setting one fourth of patients needed inpatient management while inpatient management was very few in outreaches setting for the lack of infrastructures and expertise. From emergency department four percent of the cases needed referral to another center mainly (79.8\%) for CT scan as the machine was out of order during the study period in this institution and about a half of the patients from community were referred to higher center after primary management. Similarly, Elias and Tezera also reported that they had high referral rate $(69 \%)$ for the trauma patients due to inadequacy of facilities in the emergency department. ${ }^{17}$

\section{CONCLUSION}

Fall related injuries and road traffic accidents are the commonest mode of trauma in our set up and mostly young adults in their active period of life are involved in physical trauma so appropriate in hospital management and preventive measures through public health approach should be included in comprehensive trauma management for reducing mortality and morbidity rates related to physical trauma.

\section{REFERENCES}

1. World Heath Organization [homepage on the internet]. 10 facts on injuries and violence. [ Updated 2008 Mar 12; cited 2008 Oct 25]. Avilable from: http//www.who.int/features/factfiles/injuries/en/ index.html.

2. Robyn Horton, Adnan A. Hyder, David Bishai, and Magie Penden. Disease Control Priorities in Developing Countries (2nd Ed); Unintentional Injuries; Chapter 39; page 737-53.

3. Jha N, Agrawal CS. Epidemiological Study of Road Traffic Accident Cases: A Study from Eastern Nepal. Regional Health Forum. 2004; 8(1):15-22.

4. Bhandari GP, Dhimal M, Ghimire U. Epidemiological Study in Injury and Violence in Nepal.(Report) Nepal Health Research Council Study. Nov 2009.

5. Hyder AA, Amach OH, Garg N, Labinjo MT. Estimating the burden of road traffic injuries among children and asolescents in urban South Asia. Health Policy. 2006;77(2):129-39.

6. Singh R, Bhatnagar M, Singh HK, Singh GP, Kumar Y. An Epidemiological study of victims of Road Traffic Accidents case: A Study from National Capital Region (Ghaziabad), India. Indian J Prev Soc Med. 2011; 42(1):28-33.

7. Joshi SK, Shrestha S. A Study of Injuries and Violence Related Articles in Nepal. J Nepal Med Assoc. 2009; 48(175):209-16.

8. Jha N. Road Traffic Injuries. J Nep Med Assoc. 2005; 44: 156-159.

9. Ghimire A, Nagesh S, Jha N, Niraula SR, Devkota S. An Epidemiological study of injury among urban population. Kathmandu University Medical Journal. 2009; 7(4):402-7.

10. Banthia P, Koirala B, Rauniyar A, Chaudhary D, Kharel T, Khadka SB. An epidemiological study of road traffic accident cases attending emergency department of teaching hospital. I Nep Med Assoc. 2006;45:238-43.

11. Poudel-Tandukar K, Nakahara S, Ichikawa M, Poudel KC, Joshi $A B$, Wakai S. Unitentional injuries among school adolescents in Kathmandu, Nepal: a descriptive study. Public health. 2006;120:6419.

12. Shrestha D, Garg M, Singh GK, Singh MP, Sharma UK. Cervical Spine Injuries in a Teaching Hospital of Eastern Region of Nepal: A Clinicoepidemiological Study. J Nep Med Assoc. 2007;46(167):107-111.

13. Chacko V, Joseph B, Mohanty SP, Jacob T. Management of spinal cord injury in a general hospital in India. Paraplegia. 1986 Oct;24(5):330-5.

14. Dave PK, Jayaswal A, Kotwal PP. Spinal cord injuries - A clinicepidemiological study. Ind J Orthop. 1994;28:39-45.

15. Meskin S, Huyler F, Gupta SK, Berger L. Delivery of emergency medical services in Kathmandu, Nepal. Ann Emerg Med. 1997;29:409-14.

16. Sharma G, Shrestha PK, Wasti H, Kadel T, Ghimire P, Dhungana S. A review of violent and traumatic deaths in Kathmandu, Nepal. Int J Inj Contr Saf Promot. 2006;13(3):197-9.

17. Elias A, Tezera C. Orthopedic and Major Limb Trauma at the Tikur Anbessa University Hospital, Addis Ababa - Ethiopia. East and Central African Journal of Surgery.2005;10(2):43-50. 